ISSN 2080-1653

DOI 10.24917/20801653.324.2

\author{
PRZEMYSŁAW ŚLESZYŃSKI \\ Institute of Geography and Spatial Organization, Polish Academy of Sciences, Poland
}

\title{
Research Topics of Geography of Enterprise and Decision-Control Functions in Poland against Global Trends
}

\begin{abstract}
The article is a review of the research conducted in Poland on geography of enterprise, understood as a sub-discipline within the scope of socio-economic geography, including research on the behaviour of economic entities, especially large ones, in geographical space. First, the fundamental methodological issues, including terminology, were discussed and then the source query was made. It allowed for identifying about 200 bibliographic items, of which about ten are discussed in detail as the most representative of this research speciality. The results of the study are discussed in two periods: before 1989 and after that date, as the fundamental influence of the political change and the rebirth of the free market economy in Poland after the communist period. In the modern period, three main research trends have been distinguished, referring to global research: transformational-globalisation, localisation (also called organisational-systemic) and behavioural. Moreover, urban research is discussed. In conclusion, geography of enterprise is still too weakly defined in Poland, and it is conducted from the "industry" positions of geography (especially geography of industry), which results from the institutional and organisational assumptions of the Polish socio-economic geography after the methodological conference in Osieczna in 1955.
\end{abstract}

Keywords: corporate geography; decision-control function; economic control function; geography of enterprise; transformation

Received: 5 May 2018

Accepted: 24 July 2018

\section{Suggested citation:}

Śleszyński, P. (2018). Research Topics of Geography of Enterprise and Decision-Control Functions in Poland against Global Trends. Prace Komisji Geografii Przemysłu Polskiego Towarzystwa Geograficznego [Studies of the Industrial Geography Commission of the Polish Geographical Society], 32(4), 22-47. https://doi. org/10.24917/20801653.324.2

\section{INTRODUCTION: GEOGRAPHY OF ENTERPRISE, ITS METHODOLOGICAL FOUNDATIONS AND THE EVOLUTION OF RESEARCH IN THE WORLD}

Geography of enterprise is a subdivision of socio-economic geography dealing with behaviours in the space of business entities. It has a well-established position in the world, related to the fact that in a free market economy enterprises are the primary 
subject of broadly understood economic space. Therefore, it is the subject of interest not only of geographers, but also economists, sociologists, political scientists, psychologists, urban planners and other representatives of mainly social sciences. It sometimes results in competence disputes between geography and economics (Czapliński, 2008). They are related in particular to the fact that as part of the organisation and management sciences, in the 20th century, an extensive and recognisable field of research, first described as "economics and/or organisation of enterprises" and then "enterprise science", developed in Poland before the Second World War (Bielski, 1967).

In the Western countries, research in the field of geography of enterprise and decision-control functions was conditioned by the development of industry in the first half of the 20th century. Geography interests in this subject were especially visible in the United States (Hoover, 1937), where the company headquarter was usually a place of activity (production). The beginnings of geography of enterprise were shaped, therefore, by discussing the classic theories of location, first of all of the industry (Krumme, 1969; Hamilton, 1974; Dicken, 2013). It was only in the further period that this field was linked to the services sector and theories concerning the network of centres and settlement hierarchy (Goodwin, 1965; Pred, 1974).

The concept of geography of enterprise in the context of a new research course probably appeared for the first time in 1960 in the work entitled "Towards a more humanistic economic geography: The geography of enterprise" by the quoted above economic geographer Robert B. McNee (1922-1992), associated with the Department of Geography at the University of Cincinnati. The phrase 'geography of the companies' was used in his previous work (McNee, 1958). This earlier paper included analyses of the interaction between companies and their impact on the spatial organisation of economic activity. Particularly keen interest in the subject of geography of enterprise has been noted since the 1970s, when the issues have become more frequently discussed in the literature on economic geography. In addition to studies within the more or less the classic location trend, the subject of decision-control functions, i.e. the issues of location and range of impact of company headquarters, has also developed. It has become one of the most critical issues along with the progress of globalisation, used for instance to identify the settlement hierarchy, including the so-called world cities (Friedmann, 1986; Sassen, 1991; Knox, Taylor, 1995).

There are many interlocking trends associated with corporate research in geography, based on the achievements and methodologies of various social science disciplines, as well as humanities and technical and even natural sciences. It makes this sub-discipline one of the most eclectic not only in human geography but also in a broad spectrum of social sciences. It includes:

- localisation trend, relatively the oldest and associated with research on the selection of the place of activity, including in particular the seats of management, and research on the spatial organisation of economic management and the impact of management centres ('power geography'). Within this trend, research on decision-control functions (management and control) is delimited. This trend, therefore, can be called organisational-functional (Stryjakiewicz, Wajda, 2003);

- behavioural trend, which mainly concerns spatial aspects of making decisions related to the operation of enterprises, such as location, behaviour in space, business profile, organisational and spatial structure, marketing strategy, investment decisions and others; 
- transformational-globalisation trend, related to the understanding of the enterprise as the main carrier of economic and, indirectly, social transformation in space at various territorial scales, most often international. It is a relatively recent trend, but currently the most frequent and at the same time the most interdisciplinary one;

- narrower, more specialised directions related to specific aspects of business activity and characteristics of the enterprises themselves, such as size, type of activity, degree of internationalisation, financial flows, specific areas of occurrence (e.g. cities), etc., the most original of which is the so-called financial geography, that is the research on flows and spatial impact of financial institutions ('geography of banks').

Noticeable eclecticism and sometimes even a particular methodological and terminological disruption, including the diversity of conceptual and theoretical approaches and methodologies, resulted not only in the formation, often independently of one another, of separate development paths, but also the use of many possible terms related to geography, enterprise and management. The sub-discipline discussed in this review was most often described as 'geography of enterprise' or 'geography of companies', but also 'corporate geography', 'managerial geography', 'geography of multinationals', 'organisational geography', 'management geography' and others.

However, the location of enterprise geography in the structure of socio-economic geography and the separation of it as a sub-discipline is not apparent. To a large extent, its research scope, both in Poland and in the world, coincides with traditional geography of industry. This applies not only to research methods but also to the approach to the enterprise as the entity organising space. In Polish specialist literature, J. Grzeszczak (1985), T. Stryjakiewicz $(1987,1994)$ and B. Domański (1997a) pointed it out relatively early. In turn, R. Walker (1989) claimed that enterprises operate within broader spatial structures, hence giving independence to geography of enterprise is pointless. This criticism, however, seems to have a weakness related to the fact that the objects of interest of other industry geographies are also located within more general structures and are subject to their laws.

Since the enterprise is the most important or at least one of the most critical organisational forms in economic space (in addition to households in particular), it would be difficult to imagine the omission of this subject in socio-economic geography. Therefore, the enterprise is the object - directly or implicitly - of various studies on entrepreneurship, regional development, as well as the entire spectrum of partial industry analyses among the areas of geography (of industry, services, trade, transport, etc.). It may be suspected that this is not a lack of research, but certain inertia associated with traditional divisions in socio-economic geography is the reason why Poland's geography of enterprise is not a clear sub-discipline of research, as is the case in countries with well-established free market economy.

\section{RESEARCH IN GEOGRAPHY OF ENTERPRISE IN POLAND BEFORE 1989}

The enterprise has been subject to more frequent geographic surveys in Poland since relatively recently. In the years 1945-1989, the country developed in a centrally controlled economy, and therefore the critical decisions were taken by the state. Hence, the industry-related way of perceiving human activity developed, sanctioned by the 
conference in Osieczna in 1955 (geography of industry, trade and services, transport, etc.), and subjective approaches (including humanistic and behavioural) were almost absent before 1990. Nevertheless, quite early, as already in the 1960s, a few studies were created, which with all conviction can be classified as falling into the traditional current of the contemporary geography of enterprise.

Polish economic geographers in the first place researched local service ranges in the field of wholesale trade (Eberhardt, Wróbel, 1963). The research was based on the assumption that these ranges were one of the easily obtainable indicators related to the development of regional centres at the level between the voivodeship and poviat. The results of the research were therefore of practical value because they could be included in the work on the territorial reform of the country in 1975. The quoted authors state that in the case of wholesale trade the control function was strongly centralised. The management was the Central Boards of Commerce, mostly located in Warsaw (10 units) and Łódź (5 units). Similar rules were in force for industrial plants. In later studies, R. Guzik and K. Gwosdz (2000) stated that in 1974, the management of the industrial sector was based on the existence of 8 ministries and 74 subordinate organisations. In the conditions of central planning and management, the analysis assumed predominance of Warsaw as a central location for business headquarters, and regional dependencies of the location of headquarters of regional branches were considered.

Over the next 20 years, the issues of development of the control function were practically absent from the subjects of geographic surveys. The only more comprehensive study in the whole country was the study of P. Eberhardt (1986), who repeated the research related to the spatial organisation of enterprises controlling the sphere of supply, distribution and trade. Data from 46 enterprises or institutions with regional branches were collected at that time. It turned out that only 2 out of 46 surveyed enterprises had a territorial organisation coincident with the then administrative division into 49 voivodeships; 11 divided Poland into 17 service regions, referring to the former territorial division. In addition, cities were ranked according to the number of regional branch offices located in them: Warsaw (44), Krakow (41), Wrocław (41), Katowice conurbation (40), Łódź (40), Poznań (39), Szczecin (38), Gdańsk-Gdynia (37), and Lublin (35).

In the 1980s, the first studies on Polish diaspora enterprises appeared, primarily of a documentary and actual value (Manikowska, Matykowski, Stryjakiewicz, 1985; Skalmowski, 1988). However, penetration by global companies was negligible at the time, due to the political and economic determinants, which was also emphasised in international studies (Bornschier, 1982). It was only after the political breakthrough that a comprehensive study on the impact of the power of large industrial plants on the socio-spatial structures and the organisation of space was written (Domański, 1997b, 1998). Industrial control was understood there as an industrialisation policy during the command-and-distribution period.

From the research mentioned above, it can be concluded that while in the $1960 \mathrm{~s}$ the organisation of control functions was closely related to the administrative structure, in the last decade before the collapse of the command-and-distribution system, this order has significantly eroded. In the analyses cited, it was recognised that the location of the control function proves the attractiveness of a given city as a regional centre and the more management bodies, the higher its rank in the spatial structure of the country. 
RESEARCH AFTER 1989

\section{Methodological basis}

The political and socio-economic transformation has generated an expected increase in the attention focused on the economic issues in geography. However, the research of enterprises in this discipline - as a force of inertia - were undertaken within the framework of "industries" geography, especially in geography of industry, despite several essential voices about the theoretical-methodological and organisational restructuring of this type of analysis (Chojnicki, 1996; Domański, 1997a).

As mentioned in the introduction, there is a severe methodological difficulty, involving the delineation of the research area, which is the basis for the development of research on the enterprise in a typical geographical sense, distinguishable from non-geographic approaches. One can propose a definition that is closest to the system-organisational and behavioural approach: "geography of enterprise is a sub-discipline or a research speciality within socio-economic geography, which includes the research on the location, impact and organisation of enterprises in space. This approach assumes that geography of enterprise refers to concrete, conscious human decisions. These decisions are based on features related to basic spatial relations, such as distance, direction and typological bond, i.e. the type of relationship (dependence) with the surroundings" (Śleszyński, 2007: 35, modified).

\section{The transformational-globalisation trend}

Two fundamental conditions contributed to the popularity of this trend: the political breakthrough of 1989, which was the beginning of socio-economic transformation, and the accumulation of phenomena and processes of economic interdependence, which were strongly connected with this breakthrough, including the collapse of the communist system in the countries of Central and Eastern Europe. It resulted in a natural transfer of the interest in the entire economic geography to the role of spatial transformations and shifts. T. Rachwał $(2008,2015)$ notes that geography of industry is dominated by the issue of broadly understood restructuring of spatial arrangements in various territorial scales (local, regional, national, global, etc.).

The transformational-globalisation trend is admittedly practised in Poland, but it does not facilitate its identification from the position of the geography of enterprise. The vital monographic studies that deal with the issues of business operations in space have been prepared from the "industry" positions, i.e. in particular, the geography of industry. What should be particularly mentioned is the concept of spatial adaptation of industry in the transformation period (Stryjakiewicz, 1999) (which incidentally remains one of the most original theoretical and conceptual achievements in Polish socio-economic geography after 1989), as well as the explanation of the restructuring of a traditionally industrial region (Tkocz, 2001). In turn, B. Domański (2001) dealt with the factors of locating foreign enterprises and A. Tobolska (2004a) with ownership and organisational transformations in large Polish industrial enterprises.

The transformational-globalisation trend in Polish literature of geography of enterprise is dominant. Relatively most of the studies are published in the series of the 
Studies of the Industrial Geography Commission of the Polish Geographical Society edited by Z. Zioło and T. Rachwał and published in Krakow. The studies to be mentioned include, for instance, those of P. Czapliński (2000, 2011), T. Rachwał (2003a, 2003b, 2006a, 2006b, 2013), E. Rydz, W. Szymańska (2003), S. Sala (2003, 2006), M. Niemczak (2008), A. Świdurska (2010), and W. Kilar (2009a, 2014a). The undertaken themes concern both Poland and the whole world or its parts (Zioło, 2001, 2003, 2004, 2006, 2009, 2011; Kilar 2009a, 2014a, 2014b; Raźniak, Nowotnik, 2015; Raźniak, Dorocki, Winiarczyk-Raźniak, 2016; Raźniak, Dorocki, Płaziak, 2017; Dorocki, Raźniak, 2017; Raźniak, Dorocki, Winiarczyk-Raźniak, 2018).

In the group of the transformational-globalisation studies, we can distinguish case studies of particular enterprises, both Polish (Adamczak, 1994; Parysek, 1994; Rochnowski, 1994; Tobolska, 1994; Wypchło, 1994; Rachwał, 2000a, 2000b, 2001; Klimczak, 2004; Kilar, 2006) and operating in Poland (Wilkosz, 2006; Matykowski, Tobolska, 2009; Lizak, 2009; Czapliński, Stawarska, 2010), but also in a European (Kilar, 2014b; Raźniak, Dorocki, Winiarczyk-Raźniak, Płaziak, Szymańska, 2016; Zdanowska, 2017) or global perspective (Wajda, 2003, 2006; Wajda, Zalewska, 2003; Wajda, Zorićić-Wołek, 2003; Kilar, Cieluch, 2008; Kilar, 2009b, 2010, 2011, 2014b, 2015; Bonar, 2011; Boguś, 2011; Lizak, 2012; Wdowicka, 2017). The analyses concern mainly changes in the spatial organisation. There are also several reviews, methodological and concept-model papers on this topic (Smętkowski, 2000; Stryjakiewicz, 2002; Stryjakiewicz, Wajda, 2003; Tobolska, 2006a, 2006b, 2006c, 2010; Gierańczyk, 2008). In spite of the unambiguous sometimes overtones of the title, pointing to the subjective approach to the issues of the enterprise, some of these studies are difficult to explicitly qualify to geography of enterprise, because the analyses presented in them are given from different conceptual, theoretical and methodological positions originating mainly from classical studies of geography of industry, services and tourism (Korcelli-Olejniczak, 2010; Taylor, Ciechański, 2016).

In total, the "industrial" direction in geography of enterprise (or "enterprises" in geography of industry) has proved to be the most popular today. The effect was the development of the concept mentioned above of adaptation of industrial enterprises to new management conditions after 1989 (Stryjakiewicz, 1999). The subsequent, continuation studies carried out in Poznań concern mainly the trend of geography of enterprise, called by the authors "functional and organisational-systemic" (Stryjakiewicz, 2004a; Tobolska, 2004a, 2004b; Tobolska, Matykowski, 2006).

On the other hand, in the discussed transformational-globalisation trend, one should also mention the extensive monograph of P. Śleszyński (2007), in which the accents related to the transformation of enterprises after 1989, as well as changes in their location, are evenly distributed. This paper presents a model of changes in centralisation and spatial concentration of economic control functions (GFK) in the transformation period (1989-2004) (Fig. 1). An important variable in this model is the degree of centralisation, which is introduced to avoid the need to refer to space, and which illustrates the general functional transformations in the economy. In this way, a graph of the dependence of centralisation and spatial concentration is obtained. It turns out that they are convergent until the influx of foreign capital, understood as external control, gained importance. 
Fig. 1. Model of changes in spatial centralisation and concentration of economic control functions (GFK) in the period of transformation (1989-2004)

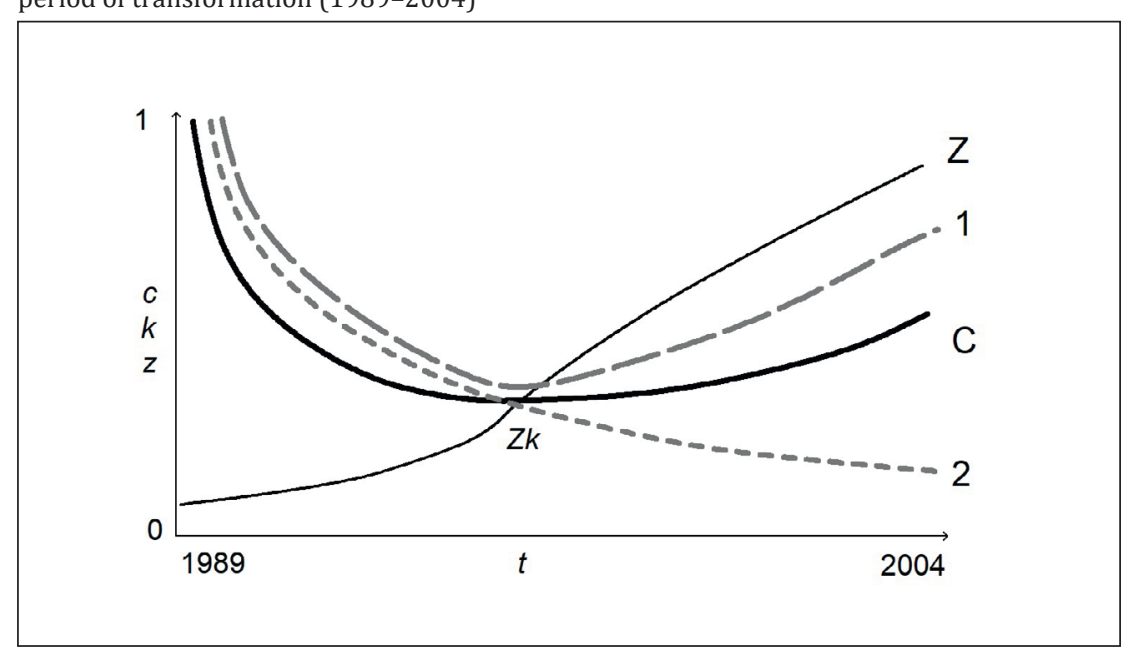

Explanations: $c, k, z$ - the degree of spatial centralisation and concentration, as well as of the inflow of foreign capital (0-1), $t$ - time (1989-2004), C - curve depicting the changes in centralisation of economic control functions (GFK), 1 - curve depicting changes in spatial concentration of economic control functions (GFK) in the industrial and financial sectors 2 - curve depicting changes in spatial concentration of economic control functions (GFK) in the retail sector; $\mathrm{Z}$ - inflow of the foreign capital, $Z k$-growth in the dynamics of the foreign capital inflow allowing for reaching the 'critical mass' sufficient enough to reverse the co-dependency trend as regards spatial decentralisation and deconcentration of economic control functions (GFK).

Source: Śleszyński (2007)

\section{Location trend and research of economic control functions}

Location trend is associated with research of the management headquarters, mainly concerning the settlement network and the functional hierarchy of cities. For this reason, the resulting studies are most often taken by urban geographers, and only then by geographers of industry. After 1989, economists G. Gorzelak (1994) and B. Wyżnikiewicz (1997), first presented the analysis of the location of the headquarters of major enterprises in Poland. Both studies pointed to a significant diversification of economic strength or economic potential in the first years of transformation, including a large concentration of company headquarters in two voivodeships: Warsaw and Katowice, and an increasing spatial polarisation in this respect.

The first "typical" survey undertaken by geographers regarding the location of economic management functions is the study of R. Guzik and K. Gwosdz (2000), which examined the concentration of control functions in industry. The research, which covered about 700 largest enterprises in Poland, showed that the management system in Poland is similar to that in the UK and France, where the control function is concentrated in one central city - the capital. Similar research, but in a dynamic system, was also conducted by H. Rogacki $(2004,2006)$.

The issues of competitiveness and the rank of large Polish cities in the light of the inflow of foreign capital were developed in the study of B. Domański, R. Guzik, K. Gwosdz (2000), where the urban centres were ranked according to the location of 
the headquarters of companies with foreign capital. In the Institute of Geography of the Jagiellonian University, there were also numerous studies on other aspects related to the location of enterprises, including the impact of transnational corporations in Poland on space (Domański, 2000, 2003a, 2005a, 2005b) and the relationship between the region and the economic power of industrial enterprises (Domański, 2003b), as well as more specialised 'sectoral/industry' issues (Guzik, Micek, 2007).

Research in the field of geography of enterprise is also being developed in Warsaw, in the Institute of Geography and Spatial Organisation of the Polish Academy of Sciences. T. Lijewski (2000) presented the analysis of the course of the planned road network concerning the headquarters of the largest Polish companies. Then E. Nowosielska (2001) presented the location of the headquarters of major enterprises in the services sector in the layout of 16 voivodeship in 1999. The issues of geography of enterprise on a national scale were also undertaken in the studies of P. Śleszyński (2002a) and T. Lijewski (2003), where a strong dominance of control functions in the capital centre was demonstrated (the so-called Warsaw hypertrophy), with a tendency to deepen it. In the paper by P. Śleszyński mentioned above, the distribution of control functions relative to settlement centres was also presented (Fig. 2). As a result, three models (schemes) of management were created, depending on the intensity of the occurrence of industry types of the largest companies and their revenues in the capital and other voivodeship and poviat centres.

The study by J. Wendt (2001) presented the spatial structure of power centres in Poland. Featured, among others, were the factors and centres of economic activity for

Fig. 2. Location models of the companies' headquarters

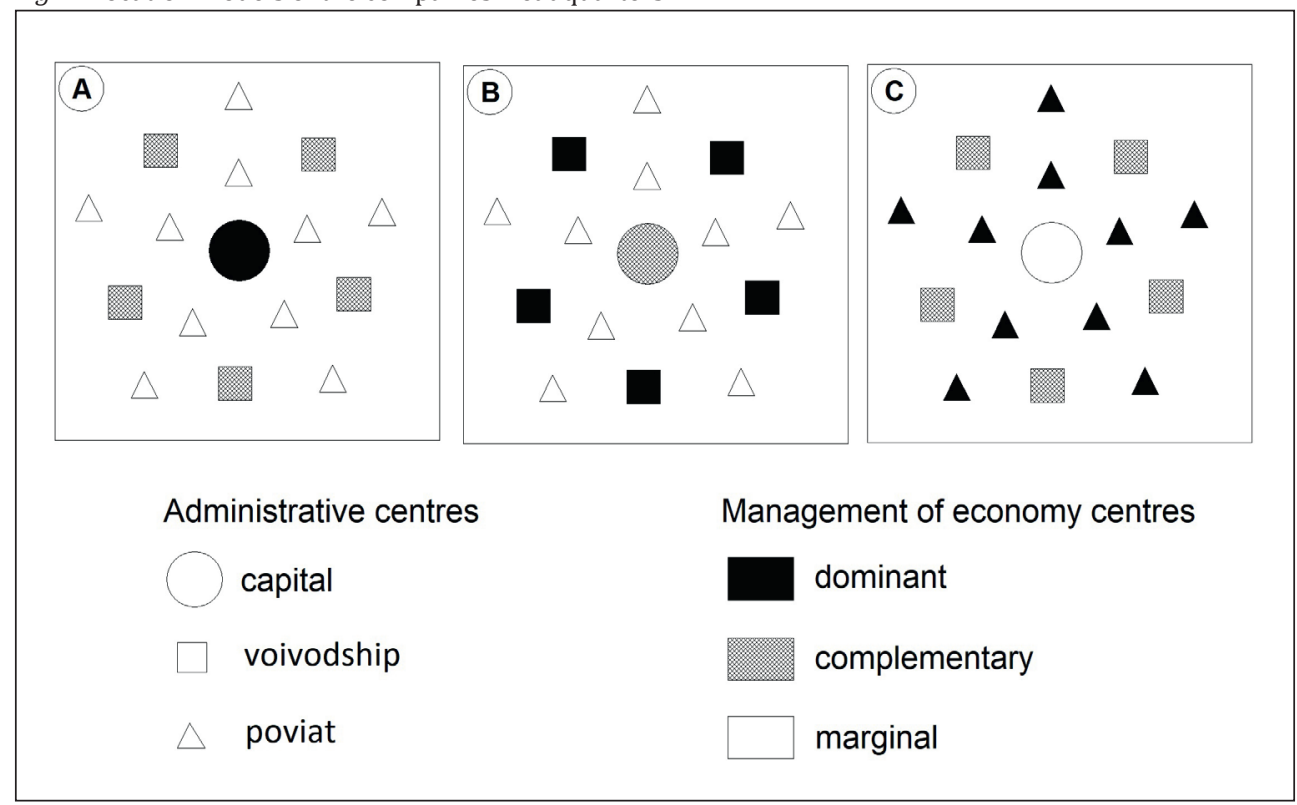

A - with the dominant role of Warsaw (highly specialised services); B - with the dominant role of voivodeship centres excluding Warsaw (low specialised services, partially manufacturing activities); C - with the dominant role of poviat centres excluding voivodeship ones (partially manufacturing services).

Source: Śleszyński (2002a) 
which the location of the main headquarter of the largest enterprises, central banks and the territorial structures of selected service networks were important. Similarly, in Poznań, individual, specific types of activities were examined, e.g. banking, a pioneer in Poland in the field of economic geography (Stryjakiewicz, Potrzebowski, 1995; Weltrowska, 2003). In the latter advanced empirical study, among others, the typology of organisational and spatial structures of banks and their networks were presented. Other studies also showed that significant differences in the distribution of spatial economic power and control functions were characteristic of regional arrangements (Śleszyński, 2002b, 2005a, 2005b, 2015; Brambert, 2010).

In the location trend, particular importance was given to the control functions of the centres. Control, as a ubiquitous phenomenon, is one of the attributes of power that enables it to exercise this power. It involves not only its common understanding as checking (obtaining information about) a given state or assessing achievements with intentions, but also observation (monitoring). Hence, in the strict sense of the word, control is a condition or stage that occurs immediately before the decision is made. The economic control function is thus one of the functions of the city, usually exogenous, through which it becomes the organising centre, and therefore subordinating and possibly dominating over the surrounding space (Śleszyński, 2002a). In this way, this function becomes the basis (base) of the node centre in the concept of the economic region. The importance of the economic control function has increased significantly in recent decades along with the growth of enterprises, which are achieving increasing trade volumes. Even around 2010, several of the largest international corporations generated revenues higher than the Polish GDP (Zioło, 2009; Śleszyński, 2013).

The location of the headquarters of the company and the place of its actual operations do not always coincide. It is especially the case of enterprises with numerous branches: enterprises of the financial sector (banking, insurance) and trade and service, and, to a slightly lesser extent, manufacturing. Therefore, the location of enterprises' headquarters does not inform about the actual distribution of manufacturing forces, but only about the distribution of decision centres, i.e. the control function. Thus, we can talk about the location of the discussed headquarters in the context of "management space".

In free market economy, the location of the company's headquarters is therefore essential. One can identify the following roles resulting from the existence of an economic control function in a given locality (Śleszyński, 2002a):

1. economic role, the most complex one, which mainly consists in various contributions to the creation of local GDP and tax discharge, depending on the possession (or not) of non-local branches, subsidiaries, etc. Owning non-local branches is characteristic of, among others, large enterprises in the services sector, especially in banking. The economic role is also participation in investments and the multiplier effect, which in this case is based on the tendency to concentrate activities in the region of the impact of the headquarters of a large enterprise (incl. financial, legal and logistic services, economic consultancy, etc.);

2. social role in which two groups of strictly related issues can be distinguished: arising from economic aspects (e.g. impact on the unemployment rate, migrations related to attracting highly qualified staff) and creating an image by raising the prestige of the city and the region, which directly translates into, for example, investment attractiveness); 
3. political role, which often results in the participation of business representatives in local authorities and thus the real impact of the company on local administration and management of the city and the region.

The specificity of the management function consists in exercising control not only over the centres, but, which may be more important from a functional point of view, over the information flow and money circulation. For this reason, financial institutions, especially banks, have the most influential position. In other words, concentrating the management control in one place results in a greater or lesser probability of interaction with another centre, and this depends on the direction of the control function development.

The most comprehensive and best-documented work in this trend is the study of P. Śleszyński (2007) regarding the shaping of economic control functions in Poland, mainly in the period of transformation (1989-2004). The research was based on the then unique revenue and shareholding bases of several thousand of the largest Polish enterprises, collected most often from annual reports or purchased from legally operating business intelligence agencies. Among other things, information was gathered on the capital relations of the largest 1,341 commercial law companies, which were analysed against the settlement structure of Poland and countries that bought shares of these companies, most often as a result of privatisation. For this purpose, the primary indicator of the strength of links was used, based on the volume of turnover and participation in the share capital. It provided the basis for developing models of ownership connections (Fig. 3) and the hypothesis of reducing cohesion and "cracking" or even "breaking" the Polish settlement system by foreign control, which became useful for the needs of the National Spatial Development Concept 2030 (Śleszyński, 2008b).

As for the above concept, it was found that in the international system, economic management centres located in Poland are subordinate in the national system: highly developed Western European countries and (besides) the United States. The main foreign control centres are concentrated in a few spatially small areas, connected in more than half with well-developed largest agglomerations, including the so-called global cities. There is a large selectivity concerning the selection of agglomerations controlling Polish centres, but they generally reflect the structure of economic governance in the owner countries. In Europe, these are primarily Amsterdam, Paris and London, in the United States - New York. In Poland, the capital city centre plays the role of the primary contact point and intermediary for further connections. In the national system, it has a strong dominant position over the entire area of the country. In this sense, referring to the Friedman centre-periphery concept, the other metropolitan centres are semi-peripheries, mainly Tri-City, Poznań, Wrocław, Katowice and Krakow, as well as some poviat towns (Płock, Lubin, and Jastrzębie-Zdrój). Other areas play the role of peripheries and are entirely dependent, primarily on Warsaw and foreign control centres, and to a lesser extent on other metropolitan areas.

However, a definite "break" of ownership bonding systems is that lower-level administrative and settlement centres are more heavily controlled by enterprises located abroad than those located at higher hierarchical levels in the country. This breaking of the existing economic hierarchy additionally confirms the concept of subordination. At the same time, in the international system, economic ties are more network-based, while in the national - polar (based on Warsaw). If we combine both observed types of relationships, we get a dependence system that in some way resembles a hierarchy (quasi-hierarchical system). This kind of connections results from the fact that the 
Fig. 3. Ownership links of the economic management centres in Poland, 2004. Cumulative links values

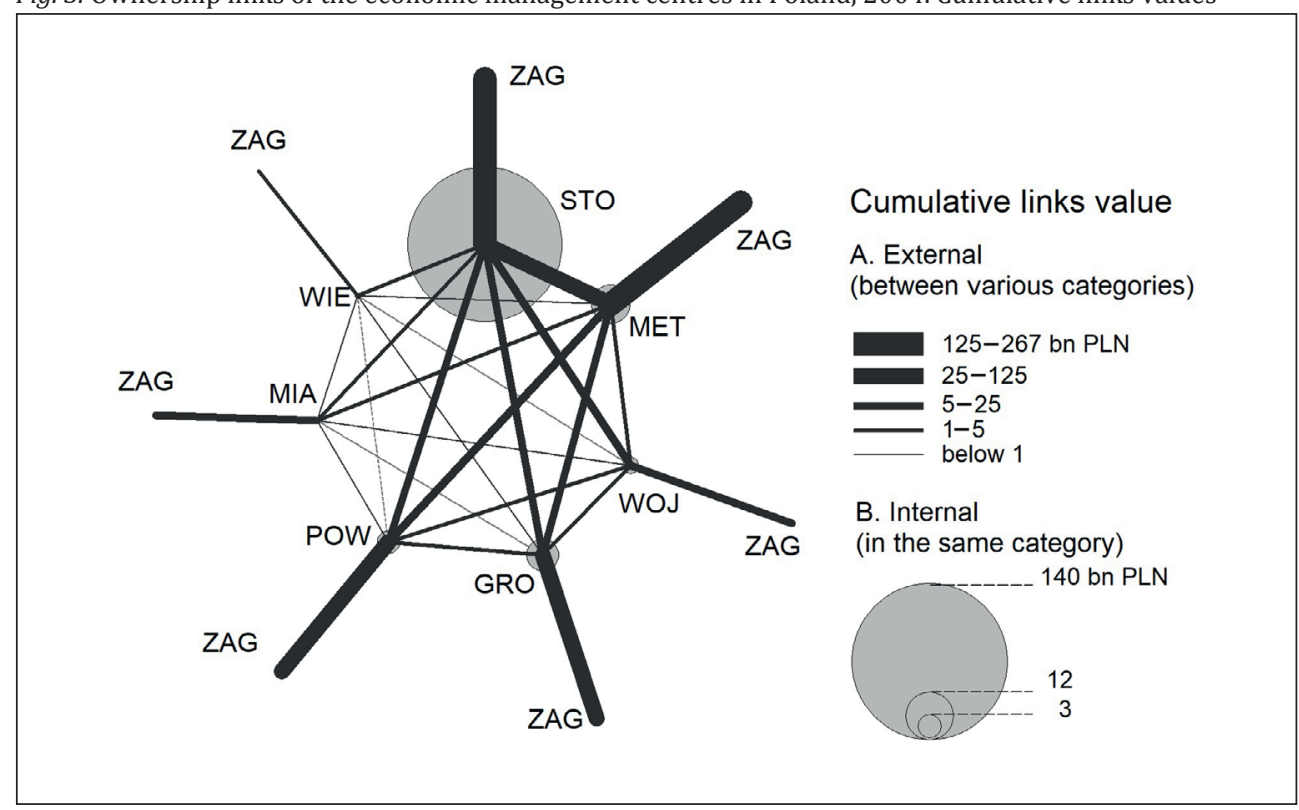

Abbreviations for administrative-settlement categories: ZAG - foreign; STO - capital; MET - other metropolitan centres; WOJ - other voivodeship centres; GRO - other poviat centres with town status; MIA - other towns and cities; WIE - villages.

Source: Śleszyński (2007)

economy in the highly developed countries functions to a large extent in the network system, and Poland is just adapting to this model.

The above analyses were later supplemented with research on the links between the organisational (Śleszyński, 2011) and geopolitical (Śleszyński, 2013) structures. The control function tests were also examined in detail in the transport sector (Taylor, Ciechański, 2010a, 2010b, 2011a, 2011b, 2013a, 2013b, 2013c, 2014, 2015). The analyses showed, among others, the concentration of transport investments in metropolitan regions, explaining such a model of location as their role as sales markets and places with good transport accessibility.

Apart from the research mentioned above, the issue of locating economic activity in new political and economic conditions was often undertaken by economists (Rakowski, 1996; Kuciński, 1998; Głowacka, 2000; Pakulska, 2001). In economists' research, it is worth noting, in particular, the study of A. Cieślik (2005), devoted in large part to the factors determining the location of foreign enterprises in Poland and the choice of management seats. This study was awarded by the Polish Economic Society.

\section{Behavioural trend}

The behavioural trend, which is one of the most commonly practised in the world, was practically still absent from Polish geography. The only major work is the already mentioned study by B. Domański (1997b), in which the decisions of large industrial enterprises and their impact on the shaping of socio-economic structures were dealt 
with. However, the behavioural or behavioural-decision-making trend is much better developed in economics and management sciences, but research in which any references to geographic conditions would be found is quite sporadic. However, recently in geography there are more and more large, comprehensive works, at least partly in the behavioural trend, in which questions are asked about the causes and motivations of spatial behaviour and decisions (Micek, 2017; Tobolska, 2017). This leads to the conclusion that we can soon except the development of this trend in Polish geography of enterprises.

\section{Research of enterprises in urban structures}

Investigations of the location and impact of enterprises within cities, well developed in the world, have not been present in Poland so far. Undoubtedly, this is because before 1989 such analyses were limited due to the different political and economic system and the possible lack of impact of the land rent on the location of economic activity. Nowadays, the issue of the location of corporate headquarters is more frequent, but it is not explicitly the main topic of research. The more detailed studies emerging after 1989 usually concerned selected cities, in particular Warsaw (Dziemianowicz, 2000; Rutkowska-Gurak, 2000; Śleszyński, 2002b, 2006, 2014) and Poznań (Tobolska, 2004a, 2014b; Stryjakiewicz, 2009), studies on the impact of individual companies (Stryjakiewicz, 2005), and selected economic sectors or function groups (Wolaniuk, 1997; Misztal, 1998; Wilk, 2001; Śleszyński, 2003; Stryjakiewicz, 2009), as well as transformations of a part of the city (Rutkowska-Gurak, 2000; May, 2001; Śleszyński, 2004), and economic zones (Domański, Gwosdz, 2005), etc. Some of these studies can be classified as part of the "traditional" geography of industry and services, or be placed within urban geography.

The two monographs of the author remain the most comprehensive urban studies (Śleszyński, 2006, 2008a). The former has a mainly documentary value because it contains the most detailed analysis, regarding both space and genre, of the distribution of economic entities in urban space to date in Poland. The latter is a detailed location record of the headquarters in the eight most significant cities of the country. Moreover, it contains the analysis which has allowed to formulate the fundamental regularities of the location distribution (Fig. 4). It states, among others, that spatial concentration is most strongly affected by the largest enterprises, the public sector and more advanced activities, especially higher-level services. They are recorded in the form of regularity the rules for the location of enterprises in urban areas:

- the principle of size. The larger the enterprise, the more often its headquarters is located in places occupying higher positions in the functional hierarchy, especially in the city centre;

- the principle of operation. The more advanced sector of the economy, the more critical area of the headquarters' location within the functional structure of the city, i.e., as in the case of the largest enterprises, in the city centre.

- the principle of ownership. Capital in its nature (similarities) chooses locations: public closer to the centres of administrative power, private - according to market potential, foreign - indirectly, most often depending on the size and type of activity (see the law of size and activity). 
Fig. 4. Location model of the firm's headquarters in the spatial structure of the city

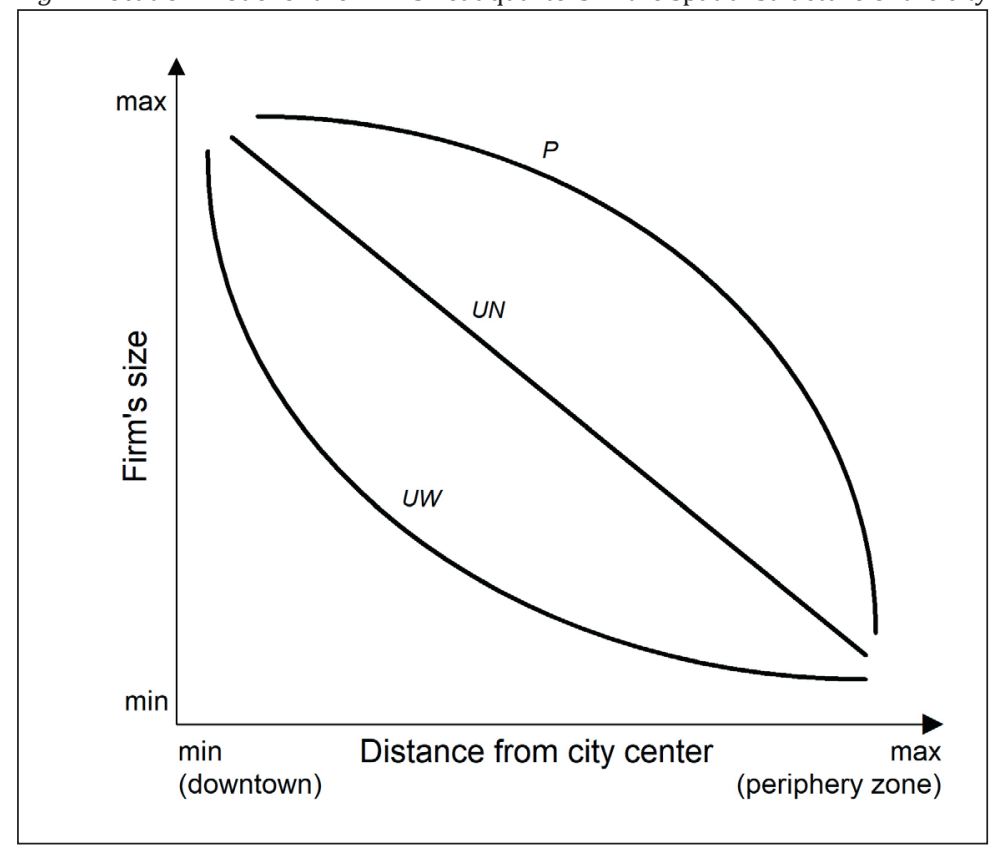

M - manufacturing, LSS - low specialised services, HSS - high specialised services.

Source: Śleszyński (2008a)

The role of the headquarters of large enterprises, as well as their interrelationships, is, therefore, one of the key (probably the most important) in shaping the Central Business District (CBD) in Polish cities during the transformation period (Śleszyński, 2004).

\section{SUMMARY}

Geography of enterprise in Poland is the sub-discipline relatively often selected for research, but it is still undetermined and only vaguely shapes its place in the structure of human geography, delineated during the post-war methodological conference in Osieczna. For this reason, it is most strongly associated with traditional geography of industry. At the present stage, the research is growing actively on the ground of localisation and transformational-globalisation trends, while in the least on the behavioural trend. Both earlier trends have been developed within the scope of industrial research and industrial economics, as well as classical or neoclassical location theories, including the theory of central places and the concept of the network of connections ('networking') and rooting of companies ('embeddedness'). The subject matter of the enterprise is inherently more frequent in research on regional development and on socio-economic transformation. Over time, the conceptual and theoretical advancement of geography of enterprise in Poland has been progressing.

The analyses concern both the entire country, as well as smaller regions and individual enterprises, especially industrial ones. There are also more and more studies on the location of companies in urban structures. Geography of enterprise is best 
developed in Krakow (Institute of Geography of the Pedagogical University, Institute of Geography and Spatial Management of the Jagiellonian University) and Poznań (Institute of Socio-Economic Geography and Spatial Management of the Adam Mickiewicz University), and also in Warsaw (Institute of Geography and Spatial Organization of the Polish Academy of Science). There are also some "geographical" studies developed by economists (Warsaw School of Economics, Cracow University of Economics, and Poznań). In other centres, studies in geography of enterprise are sporadic. The favourable peculiarity in comparison with other sub-disciplines of socio-economic geography in Poland is the relatively routine undertaking of continental and global issues.

Much more literature has been developed on the subject of geography of enterprises sensu largo, that means all geographic surveys the main subject of which is the enterprise. These are, first of all, studies on the development of entrepreneurship, in which usually all companies or all entities of the chosen sector or type of activity are analysed - and not only the largest, having a fundamental impact on the shaping of control functions. It is worth noting that the first studies in this trend appeared very soon after 1989 and concerned an important issue of foreign enterprises (Matykowski, Stryjakiewicz, 1993).

Thus, in Polish socio-economic geography, a separate and distinct sub-discipline of geography of enterprise has not been developed, but it has some original achievements that could add to the world achievements. It should be mentioned above all, includes the adaptive concept of changes in the regional industrial structure, many studies concerning individual enterprises (whose meaning goes far beyond the classically understood case study) and the concept of economic control functions along with localisation models in the spatial structure of the country and large cities.

As far as the research challenges are concerned, it still seems crucial to overcome the industry-oriented, objective way of thinking about human activity in favour of subjective approaches. Then geography of enterprise in Poland may become methodologically similar to the research conducted in Western countries and gain on cognitive and explanatory efficiency. Recently, such a landmark work in Polish socio-economic geography may be a comprehensive study of G. Micek (2017), in which the author dealt with the geographic proximity of enterprises in advanced industry and services and the flow of knowledge. The second extensive work is the study of A. Tobolska (2017), which is currently the most detailed study on the impact of enterprises in Polish area.

It is much easier to identify new research areas, not only those not addressed or scarcely outlined in the review presented, but also the analyses requiring further research using the proposed methodology. Research into business connections seems to be particularly interesting. It applies to both the ownership structure, which is considered in one of the sections here, but also links between the various organisational levels of individual enterprises. Further research is also required into the spatial and temporal scales of the impact of economic control functions, related to the structure of branches, subsidiaries, etc., and their subsequent links with other entities.

Another issue requiring further detail is the role of foreign capital in shaping the spatial diversity of economic control functions. Particularly, further research is required on the attractiveness of individual regions and cities for company headquarters, as a result of which a particular system of economic subordination is created. In particular, concepts derived from the centre and periphery model, such as the economic domination of metropolitan areas (Korcelli-Olejniczak, 2012) may be applied here. 
A huge issue is the role of the control function in shaping the spatial network organisation of the economy. The disintegration of hierarchical structures for networking, especially in the international and global context, has been one of the most specific processes in the structure of the world's economic space for two to three decades (Stryjakiewicz, 2001). It is necessary to specify the significance of ownership connections among other types of connections, especially those related to the real capital and information flow. It could lead to a more coherent and comprehensive concept of a control function in spatial and economic systems.

The possibilities of using economic control functions in related issues seem particularly appealing. Research into the distribution of company headquarters and the links between them can be useful not only in explaining the processes of socio-economic transformation, including centralisation and economic decentralisation. The particular application should be made in the studies on the formation of a new settlement structure, especially in urban systems. It would be worth combining these processes with political history after 1989 , especially with the policy of individual governments towards privatisation and, in general, the role of large enterprises in the socio-economic life of the country.

The presented proposals are of a general nature and, indeed, do not exhaust the list of available issues. Most of them should undoubtedly be the subject of in-depth empirical studies and deserve extensive monographs. Along with the deepening of knowledge, the analysis of location conditions and functional connections, a more coherent and comprehensive theory of location of management and economic control functions should be created in the conditions of transition from a centrally controlled economy to a free market economy. In total, prospects for geographic studies on geography of enterprise in Poland seem to be promising.

\section{References}

Adamczak, Z. (1994). Funkcjonowanie zakładów przemysłu mięsnego w nowych warunkach społeczno-ekonomicznych (na przykładzie Zakładów Mięsnych w Krotoszynie) [Operation of meat industry plants in new socio-economic conditions (on the example of Meat Processing Plant in Krotoszyn)]. In: Z. Zioło (ed.). Funkcjonowanie przedsiębiorstw przemysłowych $w$ zmieniajacych się warunkach gospodarowania [Functioning of industrial enterprises in changing management conditions]. Kraków: Komisja Geografii Przemysłu Polskiego Towarzystwa Geograficznego, Instytut Geografii Wyższej Szkoły Pedagogicznej, 139-147.

Bielski, M. (1967). Polska myśl naukowa w dziedzinie organizacji i kierownictwa w latach 19001939 [Polish scientific thought in the field of organisation and management in the years 1900-1939]. Problemy Organizacji, 9, 5-111.

Boguś M. (2011). Dynamika potencjału ekonomicznego korporacji ponadnarodowej Google w latach 2001-2009 [The dynamics of the economic potential of the multinational corporation Google in years 2001-2009]. Prace Komisji Geografii Przemysłu Polskiego Towarzystwa Geograficznego [Studies of the Industrial Geography Commission of the Polish Geographical Society], 17, 212-224.

Bonar, P. (2011). Funkcjonowanie korporacji Ericsson w warunkach globalnego kryzysu gospodarczego [Functioning of Ericsson company in the conditions of global economic crisis]. Prace Komisji Geografii Przemysłu Polskiego Towarzystwa Geograficznego [Studies of the Industrial Geography Commission of the Polish Geographical Society], 17, 127-211.

Bornschier, V. (1982). The world economy in the world-system: structure, dependence and change. International Social Science Journal, 34(1), 38-59.

Brambert, P. (2010). Zróżnicowanie przestrzenne siły ekonomicznej wiodących przedsiębiorstw w regionie świętokrzyskim [Spatial diversity of leading enterprises' economic power in 
the Świętokrzyskie Region], Prace Komisji Geografii Przemysłu Polskiego Towarzystwa Geograficznego [Studies of the Industrial Geography Commission of the Polish Geographical Society], 15, 156-164.

Chojnicki, Z. (1996). Socio-economic geography in the face of systematic transformation in Poland. In: Z. Chojnicki (ed.). Contemporary problems of Polish geography. Poznań: Bogucki Wyd. Naukowe.

Cieślik, A. (2005). Geografia inwestycji zagranicznych. Przyczyny i skutki lokalizacji spółek z udziałem kapitału zagranicznego w Polsce [Geography of foreign investments. Causes and effects of the location of companies with foreign capital in Poland]. Warszawa: Wydawnictwo Uniwersytetu Warszawskiego.

Czapliński, P. (2000). Przemysł drzewny na Pomorzu Środkowym w procesie przeobrażeń gospodarczych [Wood industry in Central Pomerania in the process of economic transformation]. In: Z. Zioło (ed.). Problemy transformacji struktur przemysłowych w procesie przechodzenia do gospodarki rynkowej [Problems of transformation of industrial structures in the process of transition to a market economy]. Prace Komisji Geografii Przemysłu Polskiego Towarzystwa Geograficznego [Studies of the Industrial Geography Commission of the Polish Geographical Society], 1, 67-76.

Czapliński, P. (2008). Problematyka badawcza przemysłu w geografii na tle nauk ekonomicznych [The problems of industry research in geographic and economic sciences]. Prace Komisji Geografii Przemysłu Polskiego Towarzystwa Geograficznego [Studies of the Industrial Geography Commission of the Polish Geographical Society], 11, 46-52.

Czapliński, P. (2011). Funkcjonowanie przemysłu przetwórstwa rybnego w Polsce w okresie kryzysu gospodarczego [Functioning of the fish processing industry in the period of economic crisis]. Prace Komisji Geografii Przemysłu Polskiego Towarzystwa Geograficznego [Studies of the Industrial Geography Commission of the Polish Geographical Society], 17, 114-128.

Czapliński, P., Stawarska, A. (2010). Przejawy procesu globalizacji w sferze produkcji na przykładzie Scania Production Słupsk S.A. [Signs of globalization in production sphere exemplified by Scania Production Słupsk S.A.]. Prace Komisji Geografii Przemysłu Polskiego Towarzystwa Geograficznego [Studies of the Industrial Geography Commission of the Polish Geographical Society], 16, 176-186.

Dicken, P. (2013). The geography of enterprise. Elements of a research agenda. In: M. de Smits, E. Wever (ed.). The Corporate Firm in a Changing World Economy (RLE International Business): Case Studies in the Geography of Enterprise. London-New York: Routledge, 234-244.

Domański, B. (1997a). Geografia przedsiębiorstw - niedoceniany nurt badań w polskiej geografii ekonomicznej [The geography of enterprise - an undervalued research trend in Polish economic geography. In: A. Jackowski (ed.). Geografia-Człowiek-Gospodarka. Profesorowi Bronisławowi Kortusowi w 70. rocznice urodzin [Geography-Man-Economy. To Professor Bronisław Kortus on the 70th birthday anniversary]. Kraków: Instytut Geografii Uniwersytetu Jagiellońskiego, 101-112.

Domański, B. (1997b). Industrial control over the socialist town. Benevolence or exploitation? Westport: Praeger.

Domański, B. (1998). Władza ekonomiczna a przestrzeń: przemysł w mieście w warunkach socjalizmu [Economic power and space: industry in the city in the conditions of socialism]. Czasopismo Geograficzne, 69(2), 149-167.

Domański, B. (2000). Types of investment and locational preferences of European, American and Asian manufacturing companies in Poland. In: J.J. Parysek, T. Stryjakiewicz (ed.). Polish economy in transition: spatial perspectives, Institute of Socio-Economic Geography and Space Economy. Poznań: A. Mickiewicz University, 29-39.

Domański, B. (2001). Kapitał zagraniczny w przemyśle Polski. Prawidłowości rozmieszczenia, uwarunkowania, skutki [Foreign capital in the Polish industry. Regularities of distribution, conditions, effects]. Kraków: Instytut Geografii i Gospodarki Przestrzennej Uniwersytetu Jagiellońskiego.

Domański, B. (2003a). Korporacje ponadnarodowe a transfer wiedzy w przemyśle Polski [Transnational corporations and transfer of knowledge in the Polish industry]. In: A. Kukliński (ed.). Gospodarka oparta na wiedzy. Perspektywy Banku Światowego [Knowledge- 
based economy. World Bank perspectives]. Warszawa: Komitet Badań Naukowych, Biuro Banku Światowego w Polsce, 161-164.

Domański, B. (2003b). Region a relacje władzy - przypadek województwa śląskiego [Region and power relations - the case of the Śląskie Voivodeship]. In: I. Sagan, M. Czepczyński (ed.). Wymiar i współczesne interpretacje regionu [Dimension and contemporary interpretations of the region]. Gdańsk: Katedra Geografii Ekonomicznej Uniwersytetu Gdańskiego, 91-98.

Domański, B. (2005a). Korporacje ponadnarodowe a miejsce (region) [Transnational corporations and a place (region)]. Biuletyn Komitetu Przestrzennego Zagospodarowania Kraju Polskiej Akademii Nauk, 219, 130-145.

Domański, B. (2005b) Transnational corporations and the postsocialist economy: learning the ropes and forging new relationships in contemporary Poland. In: C. Alvstam, E. Schamp (ed.). Linking Industries across the World: Processes of Global Networking. Aldershot: Ashgate, 147-172.

Domański, B., Guzik, R., Gwosdz, K. (2000). Konkurencyjność i ranga wielkich miast Polski w świetle zagranicznych firm produkcyjnych. Biuletyn Komitetu Przestrzennego Zagospodarowania Kraju Polskiej Akademii Nauk, 192, 99-124.

Domański, B., Gwosdz, K. (ed.) (2005). Dziesięć lat doświadczeń pierwszej polskiej specjalnej strefy ekonomicznej. Mielec 1995-2005 [Ten years of experience of the first Polish special economic zone. Mielec 1995-2005]. Kraków: Instytut Geografii i Gospodarki Przestrzennej Uniwersytetu Jagiellońskiego, Agencja Rozwoju Przemysłu S.A. Oddział w Mielcu, Urząd Miejski w Mielcu.

Dorocki, S., Raźniak, P. (2017). Globalne zmiany ekonomicznego centrum grawitacji w oparciu o funkcje kontrolno-zarządcze miast [Global changes of the economic center of gravity based on the control and management functions of cities]. Studia Ekonomiczne, 320, 140-156.

Dziemianowicz, D. (2000). Warszawskie przedsiębiorstwa w procesie globalizacji [Warsaw enterprises in the process of globalisation]. In: A. Kukliński, J. Kołodziejski, T. Markowski, W. Dziemianowicz (ed.). Globalizacja polskich metropolii [Globalisation of Polish metropolises]. Warszawa, Piastów: Euroreg - Europejski Instytut Rozwoju Regionalnego i Lokalnego Uniwersytetu Warszawskiego, Oficyna Wydawnicza „Rewasz”, 282-311.

Eberhardt, P. (1986). Rejonizacja przedsiębiorstw zaopatrzenia, dystrybucji i handlu hurtowego w Polsce [Zoning of supply, distribution and wholesale trade entities in Poland]. Przegląd Geograficzny, 58(4), 703-733.

Eberhardt, P., Wróbel, A. (1963). Regiony handlu hurtowego w Polsce [Regions of wholesale trade in Poland]. Przegląd Geograficzny, 35(1), 21-29.

Friedmann, J. (1986). The world city hypothesis. Development and Change, 17(1), 69-74.

Gierańczyk, W. (2008). Problematyka definiowania zmian w tendencjach lokalizacyjnych przedsiębiorstw przemysłowych $w$ dobie globalizacji [Problems in defining changes in enterprise-location tendencies in the globalization era]. Prace Komisji Geografii Przemysłu Polskiego Towarzystwa Geograficznego [Studies of the Industrial Geography Commission of the Polish Geographical Society], 11, 86-97.

Głowacka, W. (2000). Przedsiębiorstwa województwa łódzkiego na Liście 500 [Enterprises of the Łódzkie Voivodeship on the List of 500]. In: M. Sobczyński, W. Michalski (ed.). Województwo łódzkie na tle przemian administracyjnych Polski: $w$ osiemdziesiąta rocznicę utworzenia województwa [Łódzkie Voivodeship against the administrative changes in Poland: on the eightieth anniversary of the creation of the voivodeship]. Łódź: Polskie Towarzystwo Geograficzne - Oddział w Łodzi, Rządowe Centrum Studiów Strategicznych - Biuro Rozwoju Regionalnego w Łodzi, 131-137.

Goodwin, W. (1965). The Management Center in the United States. Geographical Review, 55(2), $1-16$.

Gorzelak, G. (1994). Regionalne oblicze polskiej transformacji w latach 1990-2005 [The regional face of the Polish transformation in the years 1990-2005]. Biuletyn Komitetu Przestrzennego Zagospodarowania Kraju Polskiej Akademii Nauk, 168, 9-64.

Grzeszczak, J. (1985). Stan badań nad organizacją przestrzenną przemysłu w Polsce (na tle międzynarodowym) [The state of research on the spatial organisation of industry in Poland (against the international background)]. Studia Komitetu Przestrzennego Zagospodarowania Kraju Polskiej Akademii Nauk, 82, 95-108. 
Guzik, R., Gwosdz, K. (2000). The spatial concentration of control functions in Polish industry. In: T. Marszał (ed.). Local economy and urban development in Poland, Department of the Built Environment and Spatial Policy. Łódź: University of Łódź, 52-61.

Guzik, R., Micek, G. (2007). Geography of Polish e-business. In: K. Piech (ed.). Knowledge and Innovation Processes in Central and Eastern Europe. Warszawa: Instytut Wiedzy i Innowacji, 149-159.

Hamilton, F.E.I. (ed.) (1974). Spatial perspectives on industrial organization and decision-making. London: John Wiley.

Hoover, E.M. (1937). Location theory and the shoe and leather industries. Harvard University Press, Cambridge.

Kilar, W. (2006). Przemiany funkcjonowania Zakładów Przemysłu Dziewiarskiego „Jarlan" S.A. w Jarosławiu (ze szczególnym uwzględnieniem lat 1999-2003) [Changes in the operation of the "Jarlan" Company in Jarosław, with special focus on the years 1999-2003]. Prace Komisji Geografii Przemysłu Polskiego Towarzystwa Geograficznego [Studies of the Industrial Geography Commission of the Polish Geographical Society], 9, 154-169.

Kilar, W. (2009a). Zróżnicowanie potencjału ekonomicznego światowych korporacji informatycznych [Diversification of the economic potential of global IT Corporations]. Prace Komisji Geografii Przemysłu Polskiego Towarzystwa Geograficznego [Studies of the Industrial Geography Commission of the Polish Geographical Society], 13, 110-121.

Kilar, W. (2009b). Rola korporacji Apple w kształtowaniu społeczeństwa informacyjnego [The role of the Apple corporation in shaping the information society]. PrzedsiębiorczośćEdukacja, 5, 48-56.

Kilar, W. (2010). Procesy kształtowania się korporacji Ericsson [Formation of Ericsson corporation]. Prace Komisji Geografii Przemysłu Polskiego Towarzystwa Geograficznego [Studies of the Industrial Geography Commission of the Polish Geographical Society], 16, 153-168.

Kilar, W. (2011). Wpływ kryzysu na funkcjonowanie korporacji Panasonic [The impact of the crisis on the functioning of Panasonic corporation]. Prace Komisji Geografii Przemysłu Polskiego Towarzystwa Geograficznego [Studies of the Industrial Geography Commission of the Polish Geographical Society], 17, 187-196.

Kilar, W. (2014a). Zmiany potencjału ekonomicznego wybranych korporacji informatycznych $\mathrm{w}$ warunkach kryzysu gospodarczego [Changes in the economic potential of selected information technology corporations in a context of economic crisis]. Prace Komisji Geografii Przemysłu Polskiego Towarzystwa Geograficznego [Studies of the Industrial Geography Commission of the Polish Geographical Society], 27, 57-71.

Kilar, W. (2014b). Differentiation of Visegrad Group international corporations in comparison to world's largest corporations. In: D. Kiendl Wendner, K. Wach (ed.). International competitiveness in Visegrad Countries: Macro and micro perspectives. Graz: Fachhochschule Joanneum, 171-186.

Kilar, W. (2015). Settlement concentration of economic potential represented by IT corporations. Geographia Polonica, 88(1), 123-141.

Kilar, W., Cieluch, M. (2008). Kształtowanie się i organizacja przestrzenna korporacji ponadnarodowej Honda [Formation and spatial organization of the international corporation Honda]. Prace Komisji Geografii Przemysłu Polskiego Towarzystwa Geograficznego [Studies of the Industrial Geography Commission of the Polish Geographical Society], 10, 188-203.

Klimczak, P. (2004). Przemiany funkcjonowania wiodących przedsiębiorstw dawnego COP-u: Huty Stalowa Wola S.A. i Wytwórni Sprzętu Komunikacyjnego „PZL-Rzeszów S.A. [Changes in the functioning of leading enterprises of the former Central Industrial District: Huta Stalowa Wola S.A. and Wytwórnia Sprzętu Komunikacyjnego "PZL-Rzeszów S.A.]. Prace Komisji Geografii Przemysłu Polskiego Towarzystwa Geograficznego [Studies of the Industrial Geography Commission of the Polish Geographical Society], 7, 87-96.

Knox, P., Taylor, P. (ed.) (1995). World cities in a world-system. Cambridge: Cambridge University Press.

Korcelli-Olejniczak, E. (2010). Kształtowanie się regionu metropolitalnego Warszawy w świetle analizy zasięgu działalności przedsiębiorstw sektora zaawansowanych usług [Warsaw metropolitan region in the process of making. An analysis of activity range of advanced service sector firms]. Przegląd Geograficzny, 82(4), 573-592. 
Korcelli-Olejniczak, E. (2012). Region metropolitalny. Pojęcie, struktura przestrzenna, dynamika [Metropolitan region. Concept, spatial structure, dynamics]. Prace Geograficzne, 235.

Krumme, G. (1969). Towards a geography of enterprise. Economic Geography, 45(1), 30-40.

Kuciński, K. (ed.) (1998). Współczesne uwarunkowania lokalizacji przemysłu w Polsce [Contemporary conditions of industry location in Poland]. Monografie i Opracowania, 434.

Lijewski, T. (2000). Problemy zagospodarowania przestrzennego Polski w świetle przebudowy infrastruktury komunikacyjnej [Problems of Polish spatial development in the light of reconstruction of communication infrastructure]. Dokumentacja Geograficzna, 18.

Lijewski, T. (2003). Koncentracja ośrodków aktywności gospodarczej w Polsce w świetle list 500 firm [Concentration of centers of economic activity in Poland in the light of lists of $500 \mathrm{com}$ panies]. Przegląd Geograficzny, 75(3), 433-447.

Lizak, P. (2009). Wpływ koncernu Fiat na kształtowanie się przemysłu samochodów osobowych w Polsce [Influence of the FIAT concern on the shaping of the Polish automobile industry]. Prace Komisji Geografii Przemysłu Polskiego Towarzystwa Geograficznego [Studies of the Industrial Geography Commission of the Polish Geographical Society], 12, 79-86.

Lizak, P. (2012). Kształtowanie się aliansu strategicznego firm Nissan i Renault [Development of Nissan and Renault strategic alliance]. Prace Komisji Geografii Przemysłu Polskiego Towarzystwa Geograficznego [Studies of the Industrial Geography Commission of the Polish Geographical Society], 20, 108-123.

Manikowska, B., Matykowski, R., Stryjakiewicz, T. (1985). Tendencje lokalizacyjne i struktura przestrzenna przedsiębiorstw polonijno-zagranicznych w Polsce [Location tendencies and spatial structure of Polish-foreign enterprises in Poland]. Czasopismo Geograficzne, 56(3-4), 365-377.

Matykowski, R., Stryjakiewicz, T. (1993). Foreign enterprises in an 'economy in transition'. The example of Poland. In: E.W. Schamp, G.J.R. Linge, C.M. Rogerson (ed.). Finance, institutions and industrial change spatial perspectives. Berlin: Walther de Gruyter.

Matykowski, R., Tobolska, A. (2009). Funkcjonowanie zakładów przemysłowych XXI wieku na przykładzie Swedwood Poland i Volkswagen Motor Polska Sp. z o.o.: analiza dojazdów do pracy [Operation of 21st-century industrial plants as exemplified by Swedwood Poland and Volkswagen Motor Polska Sp. z o.o.: Analysis of journeys to work]. Prace Komisji Geografii Przemysłu Polskiego Towarzystwa Geograficznego [Studies of the Industrial Geography Commission of the Polish Geographical Society], 14, 65-75.

May, J. (2001). Typy przekształceń miejskich obszarów przemysłowych w latach 90-tych: przykład Łodzi [Types of transformations of urban industrial areas in the 1990s: the example of Łódź]. Prace Komisji Geografii Przemysłu Polskiego Towarzystwa Geograficznego [Studies of the Industrial Geography Commission of the Polish Geographical Society], 3, 123-134.

McNee, R. (1958). Functional geography of the firm, with an illustrative case study from the petroleum industry. Economic Geography, 34(4), 321-37.

McNee, R. (1960). Towards a more humanistic economic geography: The geography of enterprise. Tijdschrift voor Economische en Sociale Geographie, 51(8), 201-205.

Micek, G. (2017). Bliskość geograficzna przedsiębiorstw zaawansowanego przemysłu i usług a przepływy wiedzy [Inter-firm geographical proximity in advanced manufacturing and business services versus knowledge flows]. Kraków: Instytut Gospodarki i Geografii Przestrzennej Uniwersytetu Jagiellońskiego.

Misztal, S. (1998). Przekształcenia struktury przemysłu Warszawy [Transformation of the Warsaw industry structure]. Atlas Warszawy, 6.

Niemczak, M. (2008). Przemiany struktur polskiego przemysłu cukrowniczego jako efekt procesu restrukturyzacji [Restructuring Polish sugar industry]. Prace Komisji Geografii Przemysłu Polskiego Towarzystwa Geograficznego [Studies of the Industrial Geography Commission of the Polish Geographical Society], 10, 109-122.

Nowosielska, E. (2001). Wielkie firmy usługowe w układzie nowych województw. Biuletyn Komitetu Przestrzennego Zagospodarowania Kraju Polskiej Akademii Nauk, 197, 103-129.

Pakulska, T. (2001). Główne ogniwa polskiej przestrzeni przemysłowej a atrakcyjność regionów [Main links of the Polish industrial space and the attractiveness of the regions]. Monografie i Opracowania, 480, 21-52. 
Parysek, J.J. (1994). Zachowania przestrzenne przedsiębiorstw przemysłowych w nowych warunkach społeczno-ustrojowych (na przykładzie Swarzędzkich Fabryk Mebli SA) [Spatial behaviour of industrial enterprises in new socio-political conditions (on the example of Swarzędz Furniture Plant, stock-offering company)]. Materiały i Sprawozdania Wyższej Szkoły Pedagogicznej w Krakowie, 28, 22-30.

Pred, A. (1974). Major job-providing organizations and systems in cities. Commission on College Geography, Resource Paper, 27.

Rachwał, T. (2000a). Wpływ inwestycji zagranicznych na zmiany w funkcjonowaniu Huty Szkła Jarosław S.A. w procesie transformacji gospodarczej [Impact of foreign investments on changes in the functioning of the Glassworks Jarosław P.O. in the process of economic transformation]. Rocznik Naukowo-Dydaktyczny. Akademii Pedagogicznej w Krakowie, 209, Prace Geograficzne XVIII, 209, 63-72.

Rachwał, T. (2000b). Zmiany funkcjonowania Zakładów Przemysłu Cukierniczego „San” S.A. w Jarosławiu pod wpływem inwestycji zagranicznych [Changes in the operation of the Confectionery Industry Plant „San” S.A. in Jarosław under the influence of foreign investments]. In: Z. Zioło (ed.). Działalność człowieka i jego środowisko [Human activity and its environment]. Kraków: Wydawnictwo Naukowe Akademii Pedagogicznej w Krakowie, 323336.

Rachwał, T. (2001). Funkcjonowanie Krakowskich Zakładów Elektronicznych „TELPOD” w świetle przemian $\mathrm{w}$ polskim przemyśle elektronicznym [Operation of the Kraków Electronic Works „TELPOD” in the light of changes in the Polish electronic industry]. Prace Komisji Geografii Przemysłu Polskiego Towarzystwa Geograficznego [Studies of the Industrial Geography Commission of the Polish Geographical Society], 3, 167-180.

Rachwał, T. (2003a). Globalne uwarunkowania restrukturyzacji przedsiębiorstw Polski Południowo-Wschodniej [Global conditions of restructuring of enterprises of south-eastern Poland]. Prace Komisji Geografii Przemysłu Polskiego Towarzystwa Geograficznego [Studies of the Industrial Geography Commission of the Polish Geographical Society], 6, 129-138.

Rachwał, T. (2003b). Proces restrukturyzacji przedsiębiorstw przemysłowych w Polsce Południowo-Wschodniej (na wybranych przykładach) [The process of restructuring industrial enterprises in south-eastern Poland (on selected examples)]. Prace Komisji Geografii Przemystu Polskiego Towarzystwa Geograficznego [Studies of the Industrial Geography Commission of the Polish Geographical Society], 4, 77-98.

Rachwał, T. (2006a). Efekty restrukturyzacji wybranych przedsiębiorstw przemysłowych Polski Południowo-Wschodniej [Effects of restructurings of industrial enterprises in south-east Poland]. Prace Komisji Geografii Przemysłu Polskiego Towarzystwa Geograficznego [Studies of the Industrial Geography Commission of the Polish Geographical Society], 9, 98-115.

Rachwał, T. (2006b). Restrukturyzacja technologiczna przedsiębiorstw przemysłowych Polski południowo-wschodniej jako czynnik podnoszenia ich konkurencyjności na rynku międzynarodowym [Technological restructuring of industrial enterprises in south-eastern Poland as a factor increasing their competitiveness on the international market]. Prace Komisji Geografii Przemysłu Polskiego Towarzystwa Geograficznego [Studies of the Industrial Geography Commission of the Polish Geographical Society], 8, 192-203.

Rachwał, T. (2008). Problematyka badawcza funkcjonowania przedsiębiorstw przemysłowych [Research problems concerning the functioning of industrial enterprises]. Prace Komisji Geografii Przemysłu Polskiego Towarzystwa Geograficznego [Studies of the Industrial Geography Commission of the Polish Geographical Society], 11, 53-85.

Rachwał, T. (2013). Rola przedsiębiorstw przemysłowych w rozwoju gospodarki opartej na wiedzy [The Role of Industrial Enterprises in the Development of the Knowledge-Based Economy]. Prace Komisji Geografii Przemysłu Polskiego Towarzystwa Geograficznego [Studies of the Industrial Geography Commission of the Polish Geographical Society], 21, 189-211.

Rachwał, T. (2015). Structural changes in Polish industry after 1989. Geographia Polonica, 88(4), 575-605.

Rakowski, W. (1996). Potencjał banków w układzie przestrzennym [Potential of banks in spatial layout]. In: I. Fierla (ed.). Zmiany uwarunkowań lokalizacji przemysłu w Polsce. Część II [Changes in the conditions of industrial location in Poland. Part II]. Warszawa: Szkoła Główna Handlowa, 90-100. 
Raźniak, P., Dorocki, S., Winiarczyk-Raźniak, A. (2016). Kryzys gospodarczy a funkcje kontrolno-zarządcze miast w dobie globalizacji [The economic crisis and the control and management functions of cities in the era of globalisation]. OPTIMUM Studia Ekonomiczne, 1(79), 100-117.

Raźniak, P., Dorocki, S., Winiarczyk-Raźniak, A., Płaziak, M., Szymańska, A.I. (2016). Lokalizacja ośrodków kontroli i zarządzania elementem stabilności gospodarczej ośrodków miejskich w Europie Środkowo-Wschodniej [Centres of Command and Control Location as an Element of Economic Stability in Urban Centres of Central and Eastern Europe]. Prace Komisji Geografii Przemysłu Polskiego Towarzystwa Geograficznego [Studies of the Industrial Geography Commission of the Polish Geographical Society], 30(2), 38-54.

Raźniak, P., Dorocki, S., Winiarczyk-Raźniak, A. (2018). Eastern European cities as command and control centres in time of economic crisis. Acta Geographica Slovenica, 58(2), 101-110.

Raźniak, P., Dorocki, S., Płaziak, M. (2017). Pozycja ekonomiczna miast Europy Wschodniej na tle świata [Economic position of Eastern European cities against the world]. Państwo i Społeczeństwo, 17(2), 71-87.

Raźniak, P., Nowotnik, D. (2015). Pozycja gospodarcza miast Europy Środkowo-Wschodniej na tle świata [Economic position of cities in Central and Eastern Europe against the world]. Ekonomia Międzynarodowa, 9, 23-39.

Rochnowski, R. (1994). Przekształcenia i funkcjonowanie Spółki Toruń-Pacific Company Ltd. [Transformation and functioning of the Torun-Pacific Company Ltd. company]. Materiaty i Sprawozdania Wyższej Szkoły Pedagogicznej w Krakowie, 28, 67-75.

Rogacki, H. (2004). Zmiany zróżnicowania regionalnego dużych przedsiębiorstw przemysłowych w Polsce [Transformation of regional diversity of large industrial enterprises in Poland]. In: J. Parysek (ed.). Rozwój regionalny i lokalny w Polsce w latach 1989-2002 [Regional and local development in Poland in 1989-2002]. Poznań: Bogucki Wydawnictwo Naukowe, 63-74.

Rogacki, H. (2006). Large industrial enterprises in Poland: changes in the regional pattern. Questiones Geographicae, 25, 53-59.

Rutkowska-Gurak, A. (2000). Miejski obszar przemysłowy jako środowisko lokalizacji firm (na przykładzie Służewca Przemysłowego) [Municipal industrial area as a business location environment (on the example of Służewiec Przemysłowy)]. Warszawa: Szkoła Główna Handlowa.

Rydz, E., Szymańska, W. (2003). Funkcjonowanie zakładów przemysłu obuwniczego regionu słupskiego w zmieniających się warunkach gospodarowania [Operation of footwear industry in the Słupsk region in changing management conditions]. Prace Komisji Geografii Przemystu Polskiego Towarzystwa Geograficznego [Studies of the Industrial Geography Commission of the Polish Geographical Society], 4, 43-56.

Sala, S. (2003). Wybrane cechy działalności korporacji transnarodowych i ich implikacje dla Polski [Selected features of transnational corporation's activities and their implications for Poland]. Prace Komisji Geografii Przemysłu Polskiego Towarzystwa Geograficznego [Studies of the Industrial Geography Commission of the Polish Geographical Society], 6, 101-108.

Sala, S. (2006). Polskie firmy na tle zagranicznych korporacji w dobie globalizacji [Polish corporations against foreign corporations in the age of globalization]. Prace Komisji Geografii Przemysłu Polskiego Towarzystwa Geograficznego [Studies of the Industrial Geography Commission of the Polish Geographical Society], 9, 170-180.

Sassen, S. (1991). The Global City: New York, London, Tokyo. New Jersey: Princeton University Press.

Skalmowski, W. (1988). Rozprzestrzenianie się przedsiębiorstw zagranicznych w Polsce w latach 1977-1986 [Spread of foreign enterprises in Poland in the years 1977-1986]. In: B. Jałowiecki (ed.). Percepcja, scenariusze i przedsiębiorczość [Perception, scenarios and entrepreneurship]. Warszawa: Wydawnictwo Uniwersytetu Warszawskiego.

Smętkowski, M. (2000). Przedsiębiorstwo zagraniczne w otoczeniu lokalnym [Foreign enterprise in the local environment]. Studia Regionalne i Lokalne, 4(4), 87-103.

Stryjakiewicz, T. (1987). Kierunki badawcze geografii przemysłu w Polsce w latach 1945-1980 [Research directions of the geography of industry in Poland in 1945-1980]. Materiaty i Sprawozdania COMSN, 14.

Stryjakiewicz, T. (1994). Problematyka przedsiębiorstwa przemysłowego w pracach Komisji Przemian Przemysłu i Komisji Organizacji Przestrzeni Przemysłowej Międzynarodowej Unii 
Geograficznej [Problems of an industrial enterprise in the studies of the Industrial Change Commission and the Commission of the Industrial Space Organisation of the International Geographical Union]. In: Z. Zioło (ed.). Funkcjonowanie przedsiębiorstw przemysłowych $w$ zmieniających się warunkach gospodarowania [Operation of industrial enterprises in changing economic conditions]. Kraków-Warszawa: COMSN, Komisja Geografii Przemysłu PTG, $50-56$.

Stryjakiewicz, T. (1999). Adaptacja przestrzenna przemysłu w Polsce w warunkach transformacji [Spatial adaptation of industry in Poland under transformation conditions]. Poznań: Wydawnictwo Naukowe Uniwersytetu Adama Mickiewicza.

Stryjakiewicz, T. (2001). Koncepcja usieciowienia (networking) w badaniach przestrzenno-ekonomicznych [The concept of networking in spatial-economic research]. In: H. Rogacki (ed.). Koncepcje teoretyczne i metody badań geografii społeczno-ekonomicznej i gospodarki przestrzennej [Theoretical concepts and research methods in socio-economic geography and spatial economy]. Poznań: Bogucki Wydawnictwo Naukowe, 37-47.

Stryjakiewicz, T. (2002). Orientacje teoretyczno-metodologiczne w geografii przemysłu a transformacja gospodarki [Theoretical and methodological orientations in the geography of industry and the transformation of the economy]. Prace Komisji Geografii Przemysłu Polskiego Towarzystwa Geograficznego [Studies of the Industrial Geography Commission of the Polish Geographical Society], 3, 13-27.

Stryjakiewicz, T. (2004a). Sieci gospodarcze w Polsce w warunkach transformacji systemowej [Economic networks in Poland under conditions of systemic transformation]. In: J.J. Parysek (ed.). Rozwój regionalny i lokalny w Polsce w latach 1989-2002 [Regional and local development in Poland in 1989-2002]. Poznań: Bogucki Wydawnictwo Naukowe, 25-44.

Stryjakiewicz, T. (ed.) (2005). Impact of foreign investors on regional and local development: the case of GlaxoSmithKline Pharmaceuticals S.A. in Poznań. Poznań: Bogucki Wydawnictwo Naukowe.

Stryjakiewicz, T. (2009). Lokalizacja firm i zachowania przestrzenne pracowników sektora informatycznego (na przykładzie poznańskiego obszaru metropolitalnego) [Location of firms and spatial behaviour of employees of the IT sector (the case of the Poznań metropolitan area)]. Prace Komisji Geografii Przemysłu Polskiego Towarzystwa Geograficznego [Studies of the Industrial Geography Commission of the Polish Geographical Society], 13, 21-33.

Stryjakiewicz, T., Potrzebowski, G. (1995). The newly emerging banking system in Poland and its spatial organisation. Geographische Zeitschrift, 2, 87-99.

Stryjakiewicz, T., Wajda, J. (2003). Organizacja przestrzenna grup kapitałowych jako problem badawczy geografii ekonomicznej [Spatial organisation of capital groups as a research problem of economic geography]. Prace Komisji Geografii Przemysłu Polskiego Towarzystwa Geograficznego [Studies of the Industrial Geography Commission of the Polish Geographical Society], 6, 27-47.

Śleszyński, P. (2002a). Struktura i rozmieszczenie ośrodków zarządzania w polskiej gospodarce w 2000 r. [Structure and distribution of management centers in the Polish economy in 2000]. Przegląd Geograficzny, 65(2), 199-228.

Śleszyński, P. (2002b). Koncentracja władzy gospodarczej w Krakowie i województwie małopolskim na tle kraju [Concentration of economic power in Kraków and Małopolska voivodeship against the country]. In: Z. Górka, A. Jelonek (ed.). Geograficzne uwarunkowania rozwoju Małopolski [Geographical conditions of the development of the Małopolska region]. Kraków: Oddział Krakowski Polskiego Towarzystwa Geograficznego, Koło Polskiego Towarzystwa Geograficznego w Nowym Sączu, Instytut Geografii i Gospodarki Przestrzennej Uniwersytetu Jagiellońskiego, Instytut Geografii Akademii Pedagogicznej w Krakowie, 449-461.

Śleszyński, P. (2002c). Struktura i koncentracja przestrzenna siedzib ważniejszych przedsiębiorstw w Warszawie w 1999 r. [Structure and spatial concentration of headquarters of major enterprises in Warsaw in 1999]. Prace Komisji Geografii Przemysłu Polskiego Towarzystwa Geograficznego [Studies of the Industrial Geography Commission of the Polish Geographical Society], 4, 89-114.

Śleszyński, P. (2003). Funkcje metropolitalne Warszawy - zarys problematyki [Metropolitan functions of Warsaw - an outline of the problems]. In: I. Jażdżewska (ed.). Funkcje metropolitalne i ich rola $w$ organizacji przestrzeni [Metropolitan functions and their role in spa- 
tial organisation]. Łódź: XVI Konwersatorium Wiedzy o Mieście, Katedra Geografii Miast i Turyzmu Uniwersytetu Łódzkiego, Komisja Geografii Osadnictwa i Ludności Polskiego Towarzystwa Geograficznego, Łódzkie Towarzystwo Naukowe, 119-134.

Śleszyński, P. (2004). Kształtowanie się zachodniej części centrum Warszawy [Development of the western part of Warsaw's centre]. Prace Geograficzne, 196.

Śleszyński, P. (2005a). Koncentracja działalności gospodarczej w strefie nadmorskiej Polski i jej znaczenie dla rozwoju społeczno-gospodarczego regionu [Concentration of economic activity in the coastal zone of Poland and its importance for the socio-economic development of the region]. In. M. Dutkowski (ed.). Zagospodarowanie przestrzenne i rozwój obszarów nadmorskich $w$ Polsce [Spatial development and development of coastal areas in Poland]. Szczecin: Instytut Nauk o Morzu Uniwersytetu Szczecińskiego, Oddział Szczeciński Polskiego Towarzystwa Geograficznego, 8-12.

Śleszyński, P. (2005b). Rozwój przedsiębiorstw sektora komunikacyjnego a wybrane zagadnienia sieci osadniczej i układu drogowego Polski [Development of enterprises in the communication sector and selected issues of the settlement network and the road system of Poland]. Prace Komisji Geografii Przemysłu Polskiego Towarzystwa Geograficznego [Studies of the Industrial Geography Commission of the Polish Geographical Society], 11, 65-79.

Śleszyński, P. (2006). Przedsiębiorstwa w przestrzeni Warszawy [Enterprises in the space of Warsaw]. Atlas Warszawy, 9.

Śleszyński, P. (2007). Gospodarcze funkcje kontrolne w przestrzeni Polski [Economic control functions in the space of Poland]. Prace Geograficzne, 213.

Śleszyński, P. (2008a). Duże przedsiębiorstwa w strukturze przestrzennej największych polskich miast [Large enterprises in the spatial structure of the largest Polish cities]. Prace Geograficzne, 217.

Śleszyński, P. (2008b). Ocena powiązań gospodarczych i kapitałowych między miastami [Evaluation of economic and capital ties between cities]. In: K. Saganowski, M. ZagrzejewskaFiedorowicz, P. Żuber (ed.). Ekspertyzy do Koncepcji Przestrzennego Zagospodarowania Kraju 2008-2033. Tom 1 [Expert opinions for the Concept of Spatial Development of the Country 2008-2033. Volume 1]. Warszawa: Ministerstwo Rozwoju Regionalnego, 335-391.

Śleszyński, P. (2011). Economic linkage. Studia Regionalia, 29, 49-64.

Śleszyński, P. (2013). Ekspansja przedsiębiorstw międzynarodowych a współczesna sytuacja geopolityczna Polski [Expansion of international enterprises and the contemporary geopolitical situation of Poland]. Prace Geograficzne, 242, 305-322.

Śleszyński, P. (2014). Headquarters of large enterprises in the spatial structure of major Polish cities. Prace Komisji Geografii Przemysłu Polskiego Towarzystwa Geograficznego [Studies of the Industrial Geography Commission of the Polish Geographical Society], 25, 178-193.

Śleszyński, P. (2015). Economic control functions in Poland in 2013. Geographia Polonica, 88(4), 701-708.

Świdurska, A. (2010). Efektywność rozwoju przedsiębiorstw produkcyjnych wysokiej techniki w Polsce [Efficiency of development of high-tech manufacturers in Poland]. Prace Komisji Geografii Przemysłu Polskiego Towarzystwa Geograficznego [Studies of the Industrial Geography Commission of the Polish Geographical Society], 15, 197-208.

Taylor, Z., Ciechański, A. (2010a). Niedawne przekształcenia organizacyjno-własnościowe przedsiębiorstw transportu kolejowego w Polsce - część I [Recent organisational and ownership transformations of railway transport enterprises in Poland - part I]. Przegląd Geograficzny, 82(4), 549-571.

Taylor, Z., Ciechański, A. (2010b). Organisational and ownership transformation in Poland's urban transport companies. Transport Review, 30(4), 407-434.

Taylor, Z., Ciechański, A. (2011a). Niedawne przekształcenia organizacyjno-własnościowe przedsiębiorstw transportu kolejowego w Polsce - część II [Recent organisational and ownership transformations of railway transport enterprises in Poland - part II]. Przeglad Geograficzny, 83(2), 205-231.

Taylor, Z., Ciechański, A. (2011b). Organisational restructuring and ownership transformation in Poland's inland shipping companies after 1990. Geographia Polonica, 84(2), 77-92.

Taylor, Z., Ciechański, A. (2013a). Organizacyjno-własnościowe przekształcenia narodowych przewoźników drogowych w Polsce, Czechach i na Słowacji - część II [Organisational and 
ownership transformations of national road carriers in Poland, the Czech Republic and Slovakia - part II]. Przegląd Geograficzny, 85(4), 515-547.

Taylor, Z., Ciechański, A. (2013b). Organizacyjno-własnościowe przekształcenia narodowych przewoźników drogowych w Polsce, Czechach i na Słowacji - część I [Organisational and ownership transformations of national road carriers in Poland, the Czech Republic and Slovakia - part I]. Przegląd Geograficzny, 85(2), 151-172.

Taylor, Z., Ciechański, A. (2013c). Transformacja systemowa a przekształcenia organizacyjno-własnościowe polskich przedsiębiorstw żeglugi śródlądowej [Systemic transformation and organisational and ownership transformation of Polish inland waterway companies]. Geography and Tourism, 1(1), 7-16.

Taylor, Z., Ciechański, A. (2014). Funkcje kontrolne wielkich miast Polski w świetle bezpośrednich inwestycji zagranicznych w transporcie [Control functions of large Polish cities in the light of direct foreign investments in transport]. Przeglad Geograficzny, 86(2), 141-170.

Taylor, Z., Ciechański, A. (2015). Control functions within large cities and foreign direct investment in the transport sector: Empirical evidence from Poland. Geographia Polonica, 88(4), 557-573.

Taylor, Z., Ciechański, A. (2016). Transport means and organised tourism: Empirical evidence from Poland. Geographia Polonica, 89(4), 485-504, doi: https://doi.org/10.7163/GPol.0070.

Tkocz, M. (2001). Restrukturyzacja przemysłu regionu tradycyjnego [Restructuring of industry of the traditional region]. Prace Naukowe Uniwersytetu Ślaskiego w Katowicach, 1998.

Tobolska, A. (1994). Funkcjonowanie „Amino” SA w zmieniających się warunkach ekonomicznych i społecznych [Operation of „Amino" SA in changing economic and social conditions]. Materiały i Sprawozdania Wyższej Szkoły Pedagogicznej w Krakowie, 28, 158-163.

Tobolska, A. (2004a). Zmiany własnościowe i organizacyjno-ekonomiczne w wybranych dużych przedsiębiorstwach przemysłowych Poznania w okresie transformacji [Changes in ownership and organisational-economic in selected large industrial enterprises in Poznań during the transformation period]. Poznań: Bogucki Wydawnictwo Naukowe.

Tobolska, A. (2004b). Procesy koncentracji gospodarczej przedsiębiorstw przemysłowych Poznania [Processes of economic concentration of industrial enterprises in Poznań]. Prace Komisji Geografii Przemysłu Polskiego Towarzystwa Geograficznego [Studies of the Industrial Geography Commission of the Polish Geographical Society], 7, 31-42.

Tobolska, A. (2006a). Nowy model organizacji i funkcjonowania starych przedsiębiorstw przemysłowych [A new model of the organisation and operation of old industrial enterprises]. Prace Komisji Geografii Przemysłu Polskiego Towarzystwa Geograficznego [Studies of the Industrial Geography Commission of the Polish Geographical Society], 9, 81-97.

Tobolska, A. (2006b). Przestrzenne aspekty nowej organizacji i funkcjonowania przedsiębiorstw przemysłowych [Spatial aspects of the new organisation and functioning of industrial enterprises]. Przegląd Geograficzny, 78(4), 491-513.

Tobolska, A. (2006c). Strategie globalne a nowe formy organizacji przedsiębiorstw transnarodowych [Global strategies and new forms of organisation of transnational enterprises]. Przedsiębiorczość - Edukacja, 2, 25-43.

Tobolska, A. (2010). Koncepcje teoretyczne wyjaśniające zachowanie korporacji międzynarodowych - wymiar przestrzenny [Theoretical concepts explaining the behaviour of international corporations - spatial dimension]. Ekonomista, 2, 243-258.

Tobolska, A. (2017). Strategie przedsiębiorstw międzynarodowych oraz ich oddziaływania $w$ przestrzeni lokalnej i regionalnej (na przykładzie wybranych koncernów przemysłowych w zachodniej Polsce). Poznań: Wydawnictwo Naukowe Uniwersytetu Adama Mickiewicza w Poznaniu.

Tobolska, A. Matykowski, R. (2006). Działalność przemysłowa w warunkach wzrastającej internacjonalizacji i globalizacji na przykładzie wybranych produktów [Industrial activity in the conditions of increasing internationalisation and globalisation on the example of selected products]. Prace Komisji Geografii Przemysłu Polskiego Towarzystwa Geograficznego [Studies of the Industrial Geography Commission of the Polish Geographical Society], 8, 47-59.

Wajda, E. ( 2003). Proces kształtowania się Motoroli jako firmy ponadnarodowej. Prace Komisji Geografii Przemysłu Polskiego Towarzystwa Geograficznego [Studies of the Industrial Geography Commission of the Polish Geographical Society], 5, 85-114. 
Wajda, E. (2006). Rozwój i struktura przestrzenna działalności firmy Nokia w latach 1997-2003. Prace Komisji Geografii Przemysłu Polskiego Towarzystwa Geograficznego [Studies of the Industrial Geography Commission of the Polish Geographical Society], 8, 219-240.

Wajda, E., Zalewska, K. (2003). Struktura przestrzenno-organizacyjna korporacji General-Motors. Prace Komisji Geografii Przemysłu Polskiego Towarzystwa Geograficznego [Studies of the Industrial Geography Commission of the Polish Geographical Society], 6, 119-127.

Wajda, E., Zoričič-Wołek, M. (2003). Proces kształtowania się korporacji IBM. Prace Komisji Geografii Przemysłu Polskiego Towarzystwa Geograficznego [Studies of the Industrial Geography Commission of the Polish Geographical Society], 6, 109-117.

Walker, R. (1989). A requiem for corporate geography: New directions in industrial organization, the production of place and the uneven development. Geografiska Annaler B, 71(1), 43-68.

Wdowicka, M. (2017). Miasta w globalnej sieci korporacji transnarodowych. Poznań: Wydawnictwo Naukowe Uniwersytetu Adama Mickiewicza w Poznaniu.

Weltrowska, J. (2003). Rozwój przestrzenny systemu bankowego w Polsce w latach 1989-2002 [Spatial development of the banking system in Poland in 1989-2002]. Poznań: Bogucki Wydawnictwo Naukowe.

Wendt, J. (2001). Geografia władzy w Polsce [Geography of power in Poland]. Gdańsk: Wydawnictwo Uniwersytetu Gdańskiego.

Wilk, W. (2001). Czynniki lokalizacji i rozmieszczenie wybranych usług $w$ Warszawie [Location factors and distribution of selected services in Warsaw]. Warszawa: Wydział Geografii i Studiów Regionalnych Uniwersytetu Warszawskiego.

Wilkosz, A. (2006). Procesy restrukturyzacji ALSTOM Konstal S.A. w Chorzowie [The restructuring process of the ALSTOM Konstal S.A. in Chorzów]. Prace Komisji Geografii Przemysłu Polskiego Towarzystwa Geograficznego [Studies of the Industrial Geography Commission of the Polish Geographical Society], 9, 143-153.

Wolaniuk, A. (1997). Funkcje metropolitalne Łodzi i ich rola w organizacji przestrzennej [Metropolitan functions of Łódź and their role in spatial organisation]. Szlakami Nauki, 25.

Wypchło, W. (1994). Funkcjonowanie Fabryki Samochodów Ciężarowych "STAR" w Starachowicach w nowych warunkach gospodarowania [Operation of the "STAR" Truck Factory in Starachowice in new conditions of management]. Materiały i Sprawozdania Wyższej Szkoły Pedagogicznej w Krakowie, 28, 148-157.

Wyżnikiewicz, B. (1997). Regionalne zróżnicowanie siły ekonomicznej (na podstawie „Listy 500” największych przedsiębiorstw Gazety Bankowej] [Regional diversification of economic power (based on the "List of 500" of the largest enterprises of Gazeta Bankowa)]. Studia Regionalne i Lokalne, 19(52), 205-228.

Zdanowska, N. (2017). Distribution of foreign direct investment across the national urban system in countries of Central and Eastern Europe in 2013. Geographia Polonica, 90(2), 5-24, doi: https://doi.org/10.7163/GPol.0084

Zioło, Z. (2001). Struktura branżowa i koncentracja przestrzenna wiodących światowych firm przemysłowych [Industry structure and spatial concentration of leading global industrial companies]. Prace Komisji Geografii Przemysłu Polskiego Towarzystwa Geograficznego [Studies of the Industrial Geography Commission of the Polish Geographical Society], 3, 29-42.

Zioło, Z. (2003). Kształtowanie się przedsiębiorstw przemysłowych w procesie globalizacji [The formation of industrial enterprises in the process of globalisation]. Prace Komisji Geografii Przemystu Polskiego Towarzystwa Geograficznego [Studies of the Industrial Geography Commission of the Polish Geographical Society], 6, 9-20.

Zioło, Z. (2004). Kształtowanie się firm informatycznych jako nowych elementów struktury przestrzennej [The formation of IT companies as new elements of spatial structure]. Prace Komisji Geografii Przemysłu Polskiego Towarzystwa Geograficznego [Studies of the Industrial Geography Commission of the Polish Geographical Society], 7, 97-106.

Zioło, Z. (2006). Zróżnicowanie światowej przestrzeni przemysłowej w świetle koncentracji siedzib zarządów wiodących korporacji. Prace Komisji Geografii Przemysłu Polskiego Towarzystwa Geograficznego [Studies of the Industrial Geography Commission of the Polish Geographical Society], 8, 9-26.

Zioło, Z. (2009). Procesy kształtowania się światowych korporacji i ich wpływ na otoczenie [Global corporations' shaping processes and influence on their environment]. Prace 
Komisji Geografii Przemysłu Polskiego Towarzystwa Geograficznego [Studies of the Industrial Geography Commission of the Polish Geographical Society], 12, 11-32.

Zioło, Z. (2011). Wpływ światowego kryzysu na tempo wzrostu gospodarki i światowych korporacji [The impact of global crisis on functioning of the economy and global corporations]. Prace Komisji Geografii Przemysłu Polskiego Towarzystwa Geograficznego [Studies of the Industrial Geography Commission of the Polish Geographical Society], 17, 9-32.

Przemysław Śleszyński, associate professor, head of the Department of Urban and Population Studies of IGSO PAS; member of the Scientific and Problem Committees of the Polish Academy of Sciences: Research on Migration, Demographic Sciences, Geographical Sciences, Spatial Economy and Regional Planning; chairman of the Commission for the Settlement and Population Geography of the Polish Geographical Society and vice chairman of the PGS, member of the Main Urbanistic and Architectural Commission and the Association of Polish Town Planners. Since 1997, he has been conducting research in the field of socio-economic geography and spatial economy, including urban, population, enterprise, transport and electoral geography, as well as spatial planning and regional development. Author of over 400 works in this field, including about 20 monographs.

\section{Address:}

Polish Academy of Sciences

Institute of Geography and Spatial Organization

Department of Urban and Population Studies

ul. Twarda 51/55, 00-818 Warszawa, Poland

e-mail: psleszyn@twarda.pan.pl 